\title{
sciforum
}

\section{The educational orientation offered by the Physical Education discipline in the Education-Pedagogy-Psychology specialty}

\author{
Antonio Díaz-Torriente ${ }^{a}$, Alexo Rodríguez Milian ${ }^{a}$, José Daniel Prado Mursulí $^{a}$, Odalis \\ Ruíz Pérez ${ }^{a *}$ \\ ${ }^{a}$ Department of Physical Education and Sports. Central University "Marta Abreu" de las Villas \\ (carretera a Camajuaní, Km 12 Santa Clara. Villa Clara. Cuba)
}

*Corresponding author; Email: oruiz@uclv.cu.Telephone number:+5353765929

\section{Graphical Abstract}

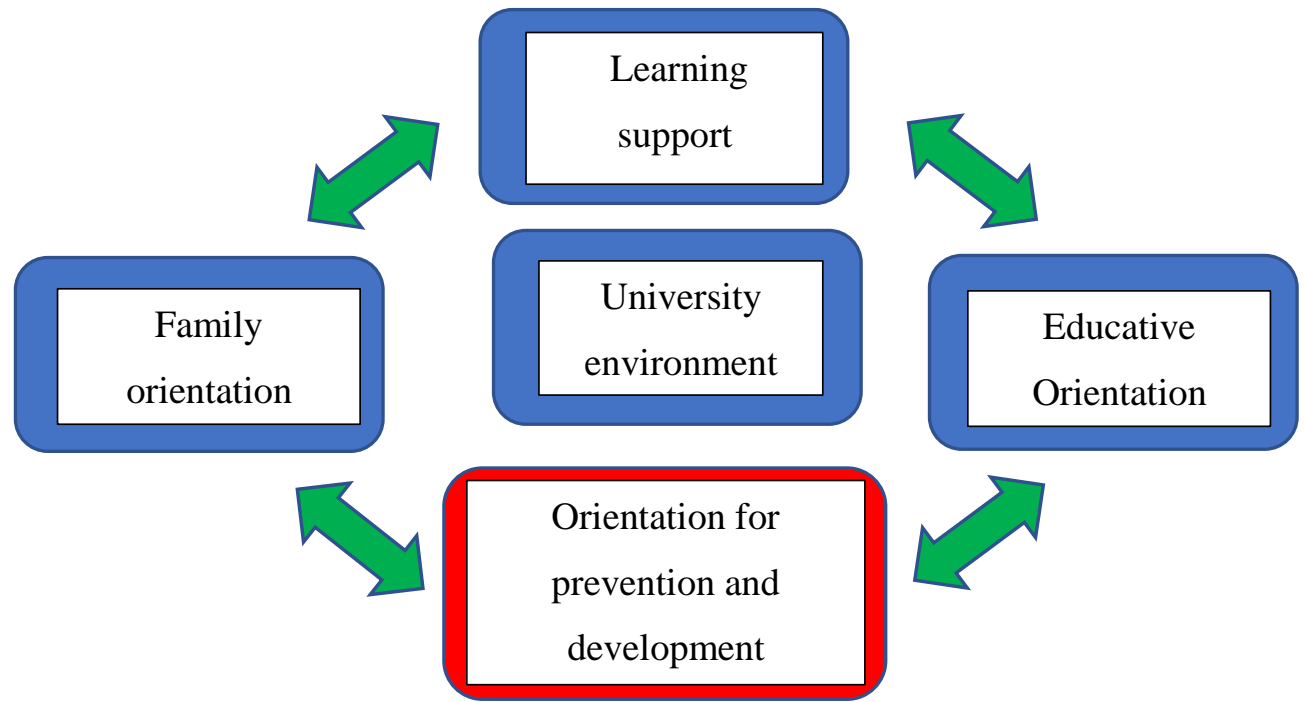

\begin{abstract}
In the Major in Education, Pedagogy-Psychology, there are many experiences as to the labor of forming pedagogical and professional abilities in the different organizational levels. These experiences could be systematized and reverted into new ways of perfecting the students' behaviors during their period of initial formation.

There is a must as to the re-design of the syllabuses for all the majoring courses in order to adapt them to the needs of the formation of an integral teacher of Psychology and Pedagogy. This re-design should include transformations on the contents to be taught, especially on the health-related contents that will play an essential role in the positive transformations of the students. Key words: physical education, syllabuses, Pedagogy, Psychology
\end{abstract}




\section{Introduction}

The above diagram shows a systematic approach that allows for the integration of the academic, workrelated and educative components, with a one-to-one correspondence between theory and practice in each teaching activity. This requires an increase in the number of activities that will ensure the formation of professional activities. The time allotted for lectures must be reduced, and the time for practical activities must be increased, which will consequently contribute to the amalgamation of the teaching and learning process as an integrated whole.

\section{Results and Discussion}

The analysis of above situation, especially as to the research voids in the formation of professional abilities, as well as the experiences of the researcher lead the investigation towards the solution of the following scientific problem:

How to contribute to the formation of professional and pedagogical abilities for the educative orientation in the students majoring in Psychology and Pedagogy by means of the discipline Physical Education? We propose the elaboration a Physical Education syllabus aimed at the formation of professional and pedagogical abilities for the educative orientation in the students majoring in Psychology and Pedagogy by means of the discipline Physical Education.

The main scientific methods used by this research include qualitative methods guided by a process of systematization of experiences and follows the seven steps and moments offered by Van de Velde (2008) whose essential requisite is to have lived the experience.

The first step consists in defining the objective of systematization, the axis and the object. The second step consists in identifying the actors, the third requires the elaboration of a systematization plan; the fourth allows for the recovery of the history. The fifth step demands for an organization of the data collected, while the sixth implies the critical interpretation and the elaboration of conclusions and the seventh and last step urges for the elaboration of communication products.

\section{Conclusion}

There is a need to re- design the syllabuses of the discipline Physical Education with an integrative approach that include the different functions expected from the teacher of Psychology and Pedagogy; this will contribute to a better development of educative orientation.

The health-related issues must acquire a fundamental role in the integral formation of the students majoring in Psychology and Pedagogy, so they have to be included in all the syllabuses of Physical Education.

\section{References}

American School Counseling Association (A.S.C.A) School Counselor Competencies. (1999). Available from: http://www.apa.org/ethics.

American School Counseling Association (A.S.C.A) School Counselor Competencies. (2008). Available from: http://www.schoolcounselor.org/files/SCCompetencies.pdf

Adelman, H. S., \& Taylor, L. School counselors and school reform: New directions, Professional School Counseling, 5, 235-248 (2002).

Ainscow, M. The next big challenge: the look of the effective school. Proceedings of International Congress on School Effectiveness and Improvement. Barcelona, Spain 2 to 5 January 2005.

Ainscow, M., Booth, T. y Dyson, A. (2006). Improving schools, developing inclusion. London: Routledge. 
